\title{
PELATIHAN PEMBUATAN ACNE DAY CREAM (KRIM SIANG JERAWAT) DAN ACNE NIGHT CREAM (KRIM MALAM JERAWAT) DI SEKOLAH MENENGAH KEJURUAN (SMK) BHAKTI KENCANA MATARAM.
}

\author{
Making Training Acne Day Cream And Acne Night Cream In Vocational High School (VHS) \\ Bhakti Kencana Mataram \\ Nening Listari $^{1^{*}}$, Numiati ${ }^{2}$, Maya Ekaningtias ${ }^{3}$, R. Didi Kuswara ${ }^{4}$, Zulkarnain Gazali ${ }^{5}$ \\ 1,2,2,4,5 Dosen Tetap Prodi Pendidikan Biologi FKIP UNW Mataram \\ *Email: nening86@gmail.com, sayanurmi3@gmail.com, mentias4life@gmail.com, \\ raden.didi@yahoo.com, zulkarnain.gazali@gmail.com,
}

\begin{abstract}
Abstrak:
Pendidikan Sekolah Menengah Kejuruan (SMK) Bhakti Kencana Mataram diselenggarakan untuk memenuhi kebutuhan belajar masyarakat khususnya di bidang kesehatan dengan program studi farmasi. Lulusan-lulusan dari SMK sangat perlu dibekali dengan keterampilan yang mendukung ilmu yang diperolehnya selama pembelajaran. Dilihat dari peminatan untuk mendapatkan keterampilan, para siswa SMK Bhakti Kencana Mataram cukup antusias, sehingga besar harapan keterampilan mereka dapat ditingkatkan melalui kegiatan Pengabdian kepada Masyarakat (PKM) oleh tim dosendosen Program Studi Pendidikan Biologi FKIP UNW Mataram tentang pelatihan pembuatan krim jerawat siang dan malam hari. Pembuatan produk krim jerawat dapat dilakukan dengan sangat mudah, menggunakan alat yang sederhana dan dengan biaya yang murah sehingga sangat potensial untuk dikembangkan menjadi produk unggulan sehingga dapat dipasarkan. Pelatihan cara pembuatan sediaan krim jerawat bagi para siswa SMK mampu meningkatan kreatifitas, keterampilan membuat sendiri kosmetika perawatan kulit serta meningkatkan jiwa wirausaha para siswa. Hal ini dapat juga membantu keluarga para siswa untuk meningkatkan tingkat ekonomi mereka.
\end{abstract}

. Kata Kunci : pelatihan, pembuatan, krim, jerawat

\begin{abstract}
:
Bhakti Kencana Mataram Vocational High School (VHS) Education is held to meet the learning needs of the community, especially in the health sector with a pharmacy study program. Graduates from SMK really need to be equipped with skills that support the knowledge they acquire during learning. Judging from the specialization in gaining skills, the students of SMK BHakti Kencana Mataram were quite enthusiastic, so it was hoped that their skills could be improved through the team of community service which are lecturers from biology education department in FKIP UNW Mataram, made a training in making acne creams day and night. Making acne cream products can be done very easily, using simple tools and at very cheap costs so that it has the potential to be developed into superior products so that they can be marketed. Training on how to make acne cream preparations day and night for vocational high school students was able to increase creativity, skills to make their own skin care cosmetics for themselves and improve students' entrepreneurial spirit. It can also help students' families to improve their economic level
\end{abstract}

Keywords : training, making, cream, acne 


\section{PENDAHULUAN}

Bagi sebagian besar wanita penampilan merupakan hal yang sangat penting. Penampilan terutama dalam menjaga kecantikan wajah sama dengan kesehatan bagi gadis usia remaja. Banyak dijumpai gadis usia remaja yang berjerawat dan timbul flek disebabkan memakai kosmetik yang mengandung merkuri dan hidrokinon. Hal itu disebabkan para remaja ingin cantik secara instan dengan memutihkan wajah. Pada dasarnya kulit remaja cenderung tidak bermasalah, hanya cenderung berminyak saja. Perawatan wajah pada remaja sebenarnya juga tidak harus berlebihan. Sesudah memasuki usia dewasa atau baligh, hormon kewanitaannya mulai aktif. Pada saat itu alangkah lebih baiknya remaja secara rutin dan konsisten merawat kulitnya demi alasan kesehatan terutama masalah jerawat. Jerawat merupakan masalah yang sering terjadi pada kulit remaja (baligh), cara mengatasinya adalah dengan memilih kosmetik yang sesuai dengan jenis kulit. Krim adalah sediaan setengah padat, berupa emulsi mangandung air tidak kurang dari $60 \%$ dan dimaksudkan untuk pemakaian luar (Depkes RI, 1979). Tujuan pembuata krim ialah untuk menghasilkan efek local (kulit) dan bukan sistemik (Syamsuni, 2006). Pembuatan krim jerawat secara mandiri lebih aman dibandingkan krim yang di beli dipasaran, hal ini dikarenakan kita dapat mengetahui komposisi bahan krim yang kita buat sendiri. Krim jerawat tidak sulit dibuat dan tidak membutuhkan biaya yang mahal dengan bahan dan peralatan yang dibutuhkan sangat sederhana, sehingga dapat diproduksi dan mempunyai nilai ekonomi.

Sekolah Menengah Kejuruan (SMK) Bhakti Kencana Mataram merupakan sekolah swasta di bidang kesehatan dengan program studi Farmasi. Di SMK bhakti kencana mataram hampir 90 persen di dominasi oleh siswa perempuan, sehingga sangat cocok jika dilakukan pengabdian masyarakat dalam hal pelatihan pembuatan krim jerawat. Selain hal tersebut siswa SMK Bhakti Kencana Mataram harus memiliki keterampilan dalam membuat sediaan krim sehingga pelatihan ini menunjang keterampilan kompetensi keahlian dari siswa SMK. Berdasarkan hal tersebut di atas, maka dosen Pendidikan biologi FKIP Universitas Nahdlatul Wathan Mataram melaksanakan pengabdian di SMK Bhakti Kencana Mataram. Bentuk pengabdian masyarakat yang kami lakukan adalah dengan memberikan pelatihan pembuatan krim jerawat siang dan malam bagi para siswa-siswi SMK Bhakti Kencana Mataram. Tujuan Pengabdian Masyarakat ini adalah untuk meningkatan kreatifitas dan keterampilan membuat sendiri kosmetika perawatan kulit serta meningkatkan jiwa wirausaha para siswa. Hal ini dapat juga membantu keluarga para siswa untuk meningkatkan tingkat ekonomi mereka.

\section{METODE PELAKSANAAN}

Langkah-langkah kegiatan pelatihan dilakukan oleh tim PKM dosen prodi Biologi FKIP UNW Mataram dengan cara mengumpulkan para siswa dan guru di suatu ruangan untuk mengikuti bimbingan dan pelatihan pembuatan sediaan krim jerawat siang dan malam dengan langkahlangkah sebagai berikut: (1) Memberi penjelasan tentang kosmetik yang aman bagi remaja (2) Menjelaskan tentang kegunaan dan keunggulan sediaan krim jerawat siang dan malam (3) Menjelaskan cara-cara pembuatan sediaan krim jerawat (4) membimbing langsung para siswa untuk membuat krim jerawat. Alat-alat yang digunakan:gelas beker, termoeter, kaki 3 , Bunsen, sendok pengaduk, timbangan milligram, mixer/ handblender. Bahan-bahan yang digunakan untuk pembuatan krim jerawat siang hari : meliputi 3 kelompok fase bahan fase A $\left(\mathrm{H}_{2} \mathrm{O}\right.$, EDTA, Zinc Oxide, Emulgen $\left.\mathrm{T}\right)$, fase $\mathrm{B}$ (white beeswax, laxemul cs, laurex cs, stearic acid, salycilic acid, CP71, BHT), fase C (anti UV $\mathrm{B}$, dimethicone, white hazel ekstrak, lemon extrak, tea tree extrak, cleocin, niacinamida, moisturizer, tea tree oil, phenoxplus72). Bahan yang digunakan untuk pembuatan krim jerawat malam hari: Fase A $\left(\mathrm{H}_{2} \mathrm{O}\right.$, EDTA, Titanium Dioxide, Emulgen T, Vegetable glycerine), Fase B (White Beeswax, laxemul $\mathrm{T}$, laxemul CS, laurex CS, CP71, Shea Light Butter, liposome, 
BHT), fase $\mathrm{C}\left(\mathrm{H}_{2} \mathrm{O}\right.$, Acnecide, niacinamide, betaine TMG), fase $\mathrm{D}$ (aloevera extrak, lavender ekstrak, honey exstrak, pitera, dimethicone, phenoxplus72). Cara pembuatan krim jerawat siang hari yaitu: (1) Campurkan bahan fase A pada sebuah wadah tahan anti panas/ glass beker, aduk rata lalu panaskan hingga $70^{\circ} \mathrm{C}$, sesekali diaduk rata, dan dalam waktu bersamaan campuran bahan fase B di panaskan sampai suhu $70^{\circ} \mathrm{C}$, biarkan semua bahan meleleh rata tanpa perlu di aduk, (2) angkat ke dua fase dari pemanas, lalu tuangkan fase B pada fase A, aduk rata 2 sampai 3 menit, (3) lanjutkan dengan mixer/ handblender sampai campuran mengental , (4) biarkan campuran fase A/B selama 1 jam, (5) tambahkan fase C satu per satu sambil di aduk rata, (6) beri pewarna 2 sampai dengan 3 tetes jika suka kemudian aduk rata serta masukkan ke dalam pot cream. Cara pembuatan krim jerawat malam yaitu: (1) Campurkan bahan fase A pada sebuah wadah tahan anti panas/ glass beker, aduk rata lalu panaskan hingga $70^{\circ} \mathrm{C}$, dan dalam waktu bersamaan campuran bahan fase $\mathrm{B}$ di panaskan sampai suhu $70^{\circ} \mathrm{C}$, biarkan semua bahan meleleh rata tanpa perlu di aduk, (2) angkat ke dua fase dari pemanas, lalu tuangkan fase B pada fase A, aduk rata 2 sampai 3 menit, (3) lanjutkan dengan mixer/ handblender sampai campuran mengental dan dingin suhu,(4) larutkan semua bahan fase C pada sebuah wadah (gelas), lalu tuang ke fase A/B, aduk rata, (5) Tambahkan Fase D satu persatu sambil diaduk rata, (6) Beri pewangi 2 s.d 3 tetes, atau pewarna, jika suka, aduk rata serta masukkan ke dalam pot cream.

\section{HASIL DAN PEMBAHASAN}

Kegiatan Pengabdian Masyarakat oleh dosen prodi Biologi FKIP UNW Mataram di SMK Bhakti Kencana Mataram dilaksanakan selama 1 hari. Kegiatan pengabdian ini meliputi pemberian penyuluhan materi selama 2 jam kemudian dilanjutkan praktek pembuatan krim selama 6 jam. Pelatihan pertama yang dilakukan adalah penyampaian materi pokok mengenai bahan kosmetik yang aman serta pembuatan krim jerawat siang dan malam hari. Metode penyampaiannya adalah ceramah dengan menggunakan media power point yang berisi tentang pengertian kosmetik, kosmetik yang aman untuk wajah, cara membuat krim jerawat siang dan malam, cara pemakaian krim jerawat, manfaat krim jerawat siang dan malam serta alat dan bahan yang digunakan. Setelah pemateri selesai memberikan materi, pemateri melakukan sesi tanya jawab untuk mengukur pemahaman peserta terhadap materi yang sudah dijelaskan. Tim membagi peserta tersebut dalam 4 kelompok yang masing-masing kelompok terdiri atas 4 dan 5 anggota peserta, setelah terbentuk kelompok peserta langsung menempati tempat praktik masing - masing sesuai kelompoknya. Kegiatan praktek ini diawali dengan mempersiapkan seluruh alat dan bahan yang akan digunakan dalam membuat krim jerawat.

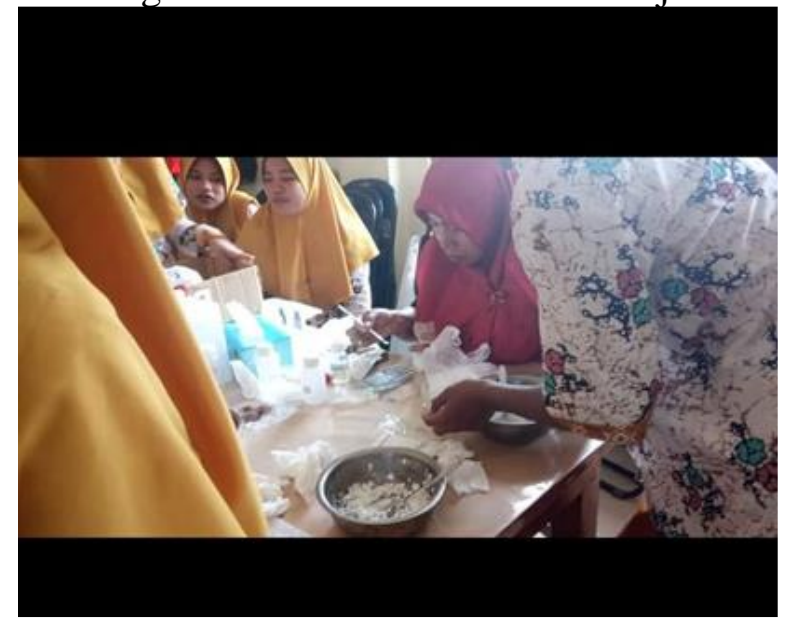

Gambar 1.1 persiapan bahan pembuatan krim jerawat

Untuk alat dan bahan praktik dibagikan secara kelompok dengan menaruhnya dalam wadah kecil yang sama jumlahnya tiap kelompok . Peserta siap dalam area kerja, kegiatan praktik membuat krim jerawat dimulai dengan arahan tim dan sambil mereview ingatan proses pembuatan krim jerawat yang telah dijelaskan sebelumnya. Hasil yang didapatkan dari kegiatan Pengabdian kepada Masyarakat ini para siswa SMK Bhakti Kencana Mataram mempunyai keterampilan membuat sediaan krim jerawat, serta para siswa juga mendapatkan informasi tentang bahan kosmetik yang aman. 


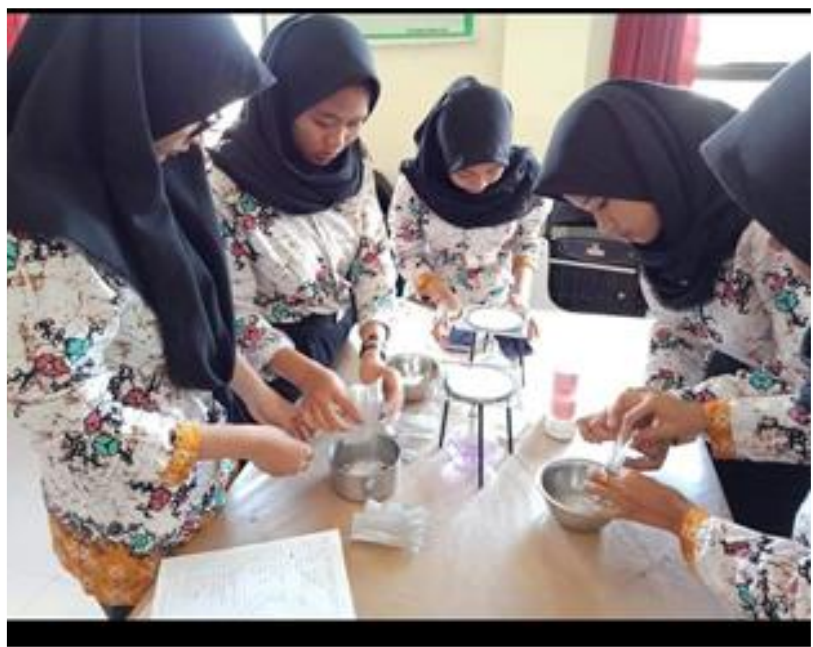

Gambar 1.2 proses pembuatan krim jerawat siang hari

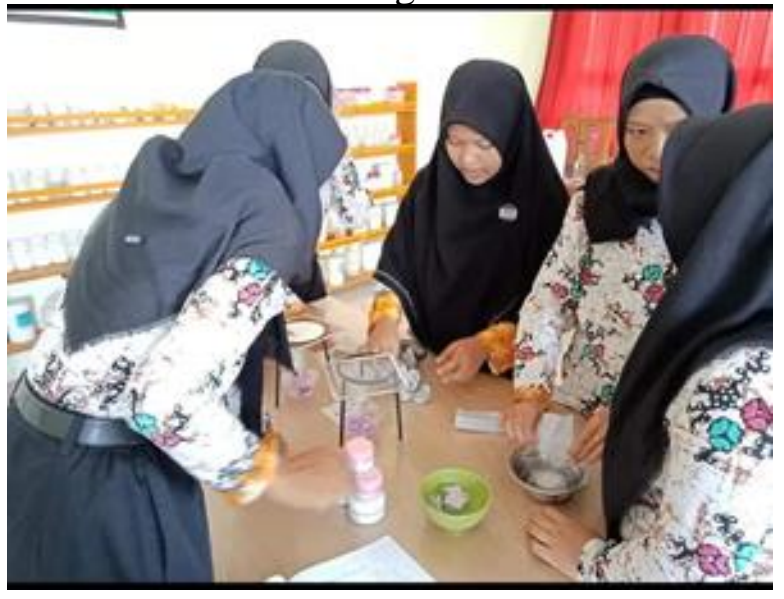

Gambar 1.3 proses pembuatan krim jerawat malam hari

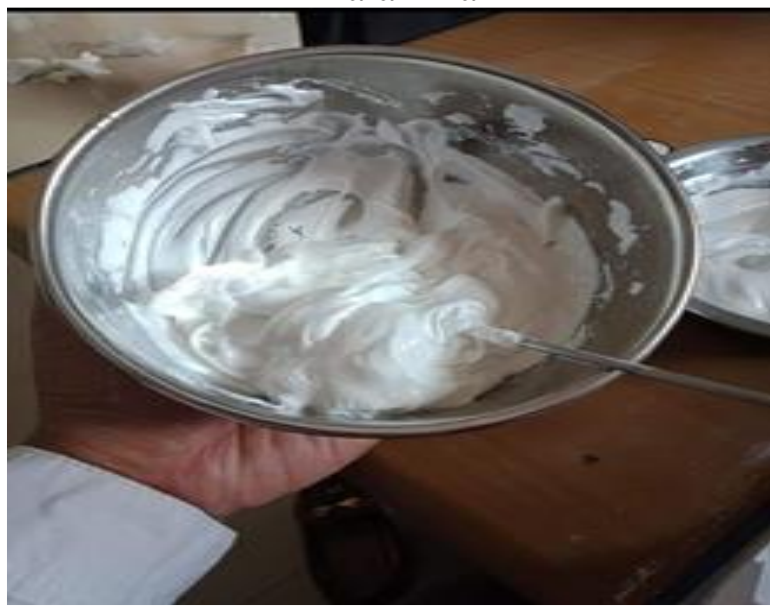

Gambar 1.4 hasil sediaan krim jerawat siang hari

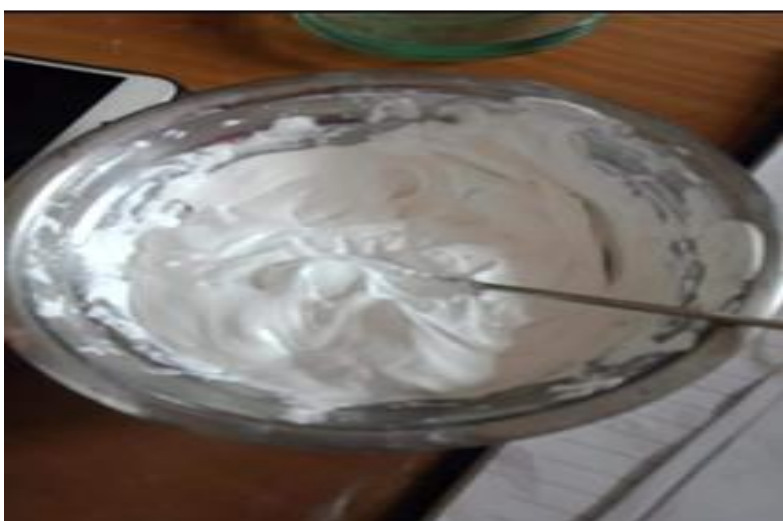

Gambar 1.5 hasil sediaan krim jerawat malam hari

Pembuatan sediaan krim mendukung kompetensi siswa sehingga membuat keterampilan siswa dalam praktikum ilmu resep semakin membaik. Selain itu Kegiatan pengabdian ini sangat di sambut dengan baik oleh pengelola SMK karena sangat bermanfaat agar siswa bisa membuka usaha mandiri. Hasil pembuatan krim siang dan malam yang telah dibuat siswa bisa langsung digunakan dan dibawa pulang.
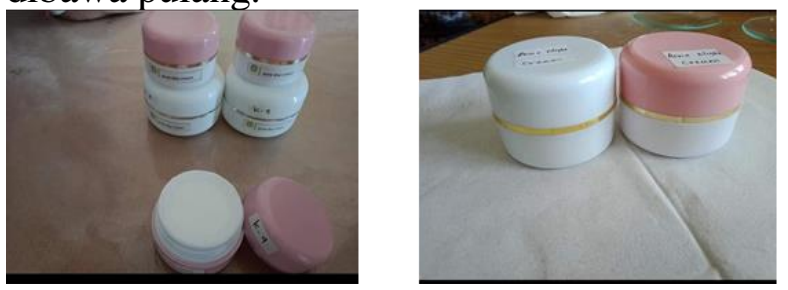

Gambar 1.6 pot krim jerawat siang dan malam

\section{KESIMPULAN}

Pelaksanaan pelatihan pembuatan krim jerawat siang dan malam di SMK Bhakti Kencana Mataram berjalan lancar dan dihadiri oleh 25 orang peserta. Pengabdian kepada masyarakat oleh dosen prodi pendidikan biologi FKIP UNW Mataram difokuskan pada kegiatan memberikan pengetahuan tentang keterampilan membuat krim jerawat siang dan malam hari. Program kegiatan pengabdian masyarakat pembuatan krim jerawat mampu menambah keteram meningkatan kreatifitas dan keterampilan para siswa-siswa di SMK Bhakti Kencana Mataram dalam pembuatan suatu sediaan kosmetik yang bernilai ekonomis dengan menggunakan teknologi yang sederhana serta meningkatkan jiwa wirausaha para siswa. Pelatihan ini juga 
mampu meningkatkan pengetahuan para siswa tentang bahan kosmetik yang aman untuk dipakai. Hasil dari pembuatan krim oleh siswa bisa langsung digunakan dan di bawa pulang.

\section{DAFTAR PUSTAKA}

Departemen Kesehatan RI (1979) Farmakope Indonesia Edisi III.

Syamsuni, H. (2006) Farmasetika Dasar dan Hitungan Farmasi. Jakarta, EGC

Hayanntunufus. 2009. Perawatan Kulit Wajah. Universitas Negeri Padang Press:Padang

Tranggono, R.I. dan Latifah, F. 2007. Buku Pegangan Ilmu Pengetahuan Kosmetik. PT.Gramedia, Jakarta. 